\title{
ОСНОВНЫЕ ИСТОЧНИКИ ЗАГРЯЗНЕНИЯ ВОД Р. АРДОН, ЕГО СТЕПЕНЬ И МАСШТАБЫ ПРОЯВЛЕНИЯ, ОЦЕНЕННЫЕ ПО РЕЗУЛЬТАТАМ ГЕОХИМИЧЕСКОГО ИЗУЧЕНИЯ ПРОБ ВОДЫ ИЗ КОНТРОЛЬНЫХ ПУНКТОВ (РСО-А)
}

\author{
А.Г. Гурбанов ${ }^{1}$, А.Б. Лолаев ${ }^{2}$, А.Б. Лексин ${ }^{3}$, С.О. Дзебо- \\ ев$^{4}$, В.М. Газеев ${ }^{5}$, А.Я. Докучаев ${ }^{6}$, Л.Е. Цуканова ${ }^{7}$, О.А. Гур- \\ банова $^{8}$, А.Х. Оганесян ${ }^{9}$, В.Э. Илаев ${ }^{10}$, М.Н. Баранова ${ }^{11}$
}

\begin{abstract}
Аннотация. В статье доказывается, что основным источником с максимальной степенью техногенного загрязнения вод р. Ардон является хвостохранилище $c$ «защитным» озером и с аномально загрязненной водой, сливаемой из него по дренажной системе в р. Ардон, в то время как ее притоки (рр. Садонка, Архондон, Уналдон) имеют второстепенное значение в этом процессе. По данным опробования р. Ардон до г. Алагир, масштабы ее загрязнения пока оцениваются в 20 км (от хвостохранилища до г. Алагир) и 30 км (от устья p. Садонки до г. Алагир). Из-за отсутствия колодиев или скважин для питьевого водоснабжения в водоносных аллювиальных горизонтах в долине р. Ардон, на отрезке от хвостохранилища и ниже по ее течению до 2. Алагир (расположен на равнине), до сих пор неизвестна степень их загрязнения за счет инфиильтрации аномально загрязненных вод «защитного» (от ветровой эрозии) озера в подземную гидросфреру, в которой могут накапливаться экологически опасные элементы. Выявленные вариации концентраций макро- и микроэлементов в водах «защитного» озера обусловлены тем, что на МГОФ, кроме руд ССЦК, могли перерабатываться кеки с завода «Электроцинк» и руды с других объектов, содержащие As, Bi, Sb, V, Cr, B, Mo, W в значительных количествах. Разные скорости течения р. Ардон в каньоне (2.3 м/сек на отрезке от хвостохранилища и до курорта Тамиск) и на равнине (1.6-1.5 м/сек в районе г. Алагир) могли привести к дифрференцированному отложению тонкодисперсного материала хвостов в донных речных отложениях. Их мощность, а соответственно и загрязняющее воздействие на воду реки в каньоне, будет меньще, чем при выходе реки на предгорную равнину, что подтверждено результатами геохимических исследований.

Ключевые слова: хвостохранилище промышленных отходов фолотации, Мизурская обогатительная фрабрика, вода в «защитном» озере, аномальные концентрации элементов, главный техногенный источник загрязнения, экологически опасные элементы, вода реки Ардон.
\end{abstract}

\section{ВВЕДЕНИЕ}

Для решения поставленных задач важно было учитывать, что на протяжении 55 лет (до 1 января 1984 года) промышленные отходы («хвосты») Мизурской горно-обогатительной фрабрики (МГОФ), с производительностью до 20000 тонн руды в сутки от переработки руд, складировались в чаше временного хвостохранилища (в узкой боковой долине левого притока р. Ардон), расположенного над пос. Мизур. МГОФ в этот период времени работала в режиме зимнего хранения хвостов и ежегодного полного их сбрасывания в р. Ардон в паводковый период. Это, вместе с попаданием в реку шахтных и производственных стоков, привело к сильному загрязнению речной воды и аллювиальных донных отложений Pb, Zn, Cu, Cd, As, Tl, Sb, B, Si, Na, Al, $\mathrm{Fe}$ и др. на всем ее протяжении до впадения в p. Терек и, возможно, далее, вплоть до Каспия, что могло привести к экологической катастрофе федерального уровня. Поэтому в 1984 г. в левом борту долины р. Ардон, в ее пойме в 500 м севернее сел. Унал, было построено новое Унальское хвостохранилище МГОФ.

В связи с тем, что Унальское хвостохранилище МГОФ оказывает интенсивное и постоянное негативное воздействие на экосистему Алагирского района в течение многих десятков лет $[5 ; 6 ; 7 ; 8 ; 1$; 2], были проведены комплексные исследования поверхностных водотоков в районе деятельности Са-

\footnotetext{
${ }^{1}$ Гурбанов Анатолий Георгиевич - к. г-м. н., в. н. с. КНИО ВНЦ РАН, г. Владикавказ; в. н. с. лаборатории петрографии ИГЕМ PAH, г. Москва (gurbanov@igem.ru).

2 Лолаев Алан Батразович - д. т. н., профессор, зав. каф. ФГБОУ СКГМИ (ГТУ), гл. н. с. КНИО ВНЦ РАН, г. Владикавказ (abl-2010@mail.ru).

3 Лексин Алексей Борисович - сотрудник лаборатории «Геоинформатики», ИГЕМ PAH, г. Москва (lexin@igem.ru).

${ }_{4}^{4}$ Дзебоев Станислав Олегович - аспирант ФГБОУ СКГМИ (ГТУ), г.Владикавказ (dzeboev.stas@mail.ru).

5 Газеев Виктор Магалимович - к. г-м. н., с. н. с. КНИО ВНЦ РАН, г. Владикавказ; н. с. лаборатории петрографии ИГЕМ

PAH, г. Москва (gazeev@igem.ru).

${ }^{6}$ Докучаев Александр Яковлевич - к. г-м. н., с. н. с. ИГЕМ РАН.

Цуканова Лада Евгеньевна - н. с. НИИ Физики ЮФУ, г. Ростов на Дону (gur_o@mail.ru)

${ }^{8}$ Оганесян Алексан Хачатурович - к.т.н. доцент, "СК ГМИ (государственный технологический университет)»,

г. Владикавказ, к. т. н., Н. с.; ВНЦ РАН, Россия, г. Владикавказ (pushkin1984@rambler.ru).

${ }^{9}$ Гурбанова Ольга Александровна - к.х.н., ассистент кафедры минералогии и кристаллохимии геологического фракультета МГУ им. М.В. Ломоносова, г. Москва.

10 Илаев Виталий Эрикович - аспирант ФГБОУ СКГМИ (ГТУ), г. Владикавказ (ive.2015@yandex.ru).

${ }^{11}$ Баранова Мария Николаевна - старший лаборант лаборатория Геоинформатики ИГЕМ РАН. Россия, г. Москва (hibari@mail.ru).
} 
донской свинцово-цинковой компании (ССЦК) и на прилегающих территориях в бассейне р. Ардон (с притоками) для геохимической характеристики отобранных проб воды. Были определены содержания макро- и микроэлементов в водах в контрольных пунктах р. Ардон - основной водной артерии, дренирующей (вместе с боковыми притоками) район деятельности ССЦК от ее верховий (район пос. Бурон) и до выхода на предгорную равнину (южная окраина г. Алагира).

Комплексные исследования проводились в июле 2015 г. Полученные результаты геохимических анализов позволили выявить в воде р. Ардон, при ее выходе на предгорную равнину, аномальные концентрации ряда макро- и микроэлементов (Pb, Zn, As, Bi, Cu, S, TI и др.), характерных для руд Садонского рудного поля. Для выявления главных техногенных и природных источников загрязнения вод р. Ардон были отобраны и проанализированы пробы из: контрольных пунктов р. Ардон и ее основных притоков; «защитного» (от эоловой эрозии пляжной части) озера, расположенного на поверхности Унальского хвостохранилища; из пульпопровода. Хвостохранилище находится в густонаселенном районе в долине р. Ардон, в 500 м севернее сел. Унал и напротив сел. Зинцар. Его площадь око-

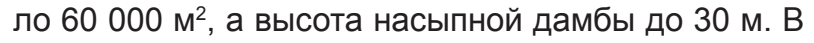
нем захоронено 2.6 млн тонн промышленных отходов с содержаниями, по данным МГОФ (в мас. \%): $\mathbf{P b}-0.21, \mathbf{Z n}-0.32, \mathbf{C u}-0.1, \mathbf{F e}-6.2, \mathbf{T i}-0.18, \mathbf{M n}$ - 0.16 и $\mathbf{A g}-4.2$ г/т. Важно отметить, что ложем хвостохранилища являются аллювиальные галечники и пески р. Ардон, через которые может осуществляться инфильтрация аномально загрязненных вод «защитного» озера в подземную гидросферу. Восточный борт хвостохранилища отделен от русла р. Ардон насыпной дамбой, укрепленной с низовой стороны железобетонной подпорной стеной, западный - близко (до 20 м) подходит к автотрассе «Транскам». Хвосты обогащения трубопроводным гидротранспортом подаются в чашу хранилища, в которой устроено водосборное сооружение шахтного типа с отводящим трубопроводом, по которому осуществляется сброс в р. Ардон осветленной части «воды» из поверхностного (до 0.2-0.3 м) слоя «защитного» озера.

При интенсивном орошении значительная часть (до 80-90 \%) хвостов находится под зеркалом воды, что затрудняет как ветровую эрозию пляжной части, так и доступ кислорода в глубокие слои, это замедляет процессы окисления находящихся в хвостах сульфидов [1].

\section{МЕТОДИКА ОТБОРА ПРОБ И МЕТОД ИХ ИССЛЕДОВАНИЯ}

Для решения поставленных задач была разработана схема опробования (рис. 1), включающая отбор проб воды как из контрольных пунктов в р. Ардон, расположенных выше (фоновая проба на южной окраине пос. Бурон) и ниже (включая выход

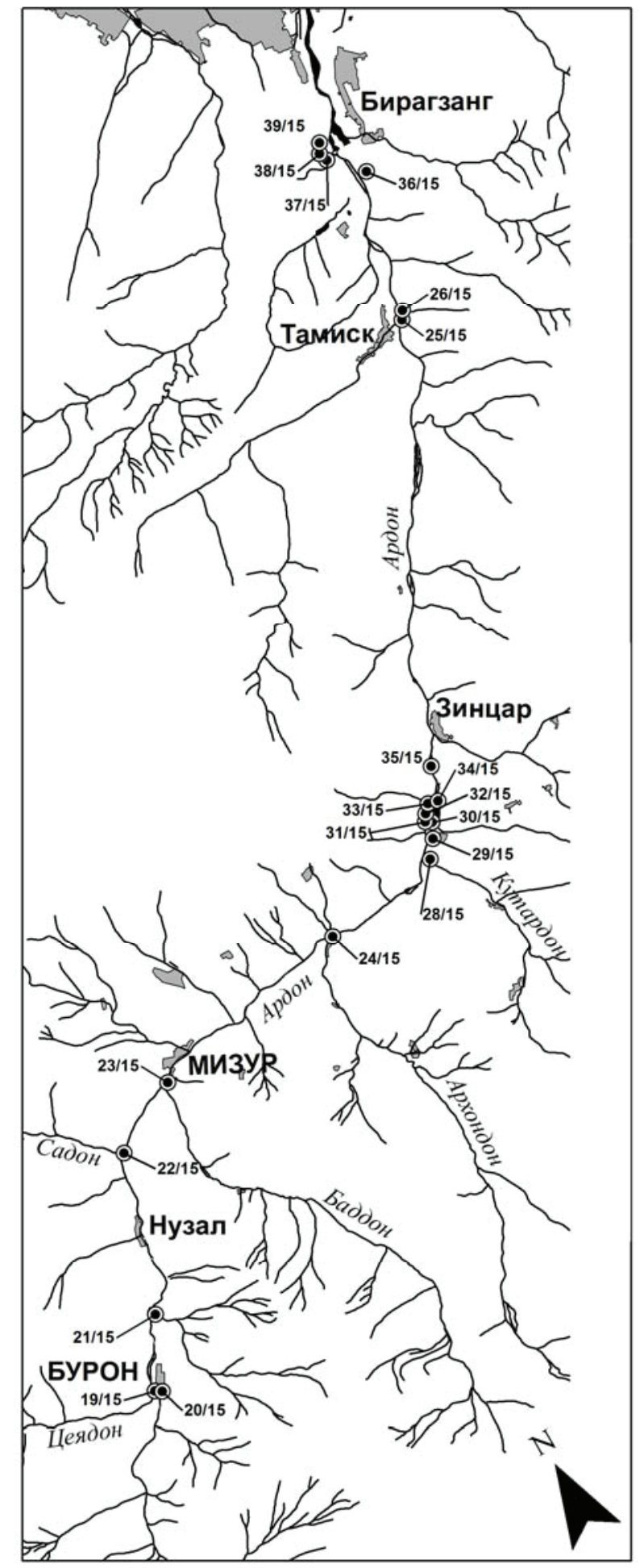

Puc. 1. Места расположения контрольных пунктов опробования вод р. Ардон и ее притоков

реки на предгорную равнину) по течению от Садонской группы месторождений и хвостохранилища, так и из устьев ее основных притоков, загрязненных стекающими в них шахтными водами. Следует отметить, что на рис. 1 показаны места отбора проб в 2015 году, однако отбор проб в 2010, 2013 и 2014 годах осуществлялся с помощью GPS-приемников 
в тех же самых местах, что и в 2015 г. Такая схема опробования и анализ проб проводились для выявления основных источников загрязнения главной водной артерии района - р. Ардон и ее притоков. Кроме того, пробы воды отбирались и из «защитного озера» Унальского хвостохранилища. При опробовании учитывались погодные условия: приоритетным было продолжительное отсутствие дождей, так как дождевая вода довольно сильно разбавила бы (в неизвестной степени) речную воду и исказила бы истинные концентрации в ней макро- и микроэлементов.

Пробы воды отбирались в чистые 0.33 мл пластиковые бутылки и подкислялись 1 мл $10 \%$ азотной кислоты и герметично закрывались.

Элементный анализ проб воды проведен атомно-эмиссионным (iСАР-6500, Thermo Scientific, США) и масс-спектральным методами с индуктивно связанной плазмой ICP-MS (X-7, Thermo Elemental, США) в Аналитическом сертификационном испытательном центре Федерального государственного бюджетного учреждения науки Институте проблем технологии микроэлектроники и особо чистых материалов РАН (АСИЦ ИПТМ РАН) с использованием стандартного образца питьевой воды «Trace Metalsin Drinking Water» производства High-Purity Standards (США) [2]. При МС-измерениях пробы разбавляли в 20 раз.

\section{РЕЗУЛЬТАТЫ АНАЛИТИЧЕСКИХ ИССЛЕДОВАНИЙ ПРОБ ВОДЫ ИЗ КОНТРОЛЬНЫХ ПУНКТОВ}

Результаты аналитических исследований отобранных в контрольных пунктах в 2015 г. проб воды приведены в таблище 1.

\section{ОБСУЖДЕНИЕ РЕЗУЛЬТАТОВ ГЕОХИМИ- ЧЕСКИХ ИССЛЕДОВАНИЙ ПРОБ ВОДЫ}

В пробах определялись концентрации широкого круга элементов (таблица 1). При анализе концентраций элементов выделены те из них, концентрации которых превышают ПДК для питьевой воды в разы, и поэтому они несут угрозу окружающей среде по различным классам опасности. Выделяют следующие классы опасности элементов: 1-й класс (TI, U, As, Be, Hg) - чрезвычайно опасные. Экологическая система необратимо нарушена. Период восстановления отсутствует. 2-й класс (Cd $\mathrm{Sb}, \mathrm{W}, \mathrm{Bi}, \mathrm{B}, \mathrm{Na}, \mathrm{Si}, \mathrm{Cr}, \mathrm{Co}, \mathrm{Ni}, \mathrm{Sr}, \mathrm{Ba}, \mathrm{Pb}, \mathrm{Li}, \mathrm{Cd}$, $\mathrm{Sb}, \mathrm{W}, \mathrm{Bi}$ ) - высоко опасные. Экологическая система сильно нарушена. Период восстановления не менее 30 лет после полного устранения источника вредного воздействия. 3-й класс (Mo, Mg, Al, Ti, V, $\mathrm{Mn}, \mathrm{Fe}, \mathrm{Cu}, \mathrm{Zn})$ - умеренно опасные. Экологическая система нарушена. Период восстановления не менее 10 лет после снижения вредного воздействия от существующего источника. 4-й класс (S, K, Ca) - малоопасные. Экологическая система нарушена. Период восстановления не менее 3 лет.
Для выявления основных техногенных и природных источников загрязнения вод р. Ардон, а также степени и масштабов его проявления была взята фоновая проба (ФП) из р. Ардон на южной окраине пос. Бурон, в которой не было выявлено превышений ПДК ни по одному элементу, и находится это место за пределами Садонского рудного поля.

Для сравнительного анализа с ФП были опробованы боковые притоки р. Ардон, в долинах которых расположены полиметаллические месторождения Садонского рудного поля. Для получения суммарного результата по загрязнению вод этих боковых притоков самоизливающимися шахтными водами пробы отбирались в их устьях.

Определение степени, масштабов и основных источников загрязнения вод р. Ардон в целом на отрезке от пос. Бурон (ФП 20/15) до хвостохранилища (проба 29/15 - в 300 м перед хвостохранилищем, т. е. за счет боковых притоков) и на предгорной равнине на южной окраине г. Алагир (проба 36/15), т. е. суммарное загрязнение.

Содержание макро- и микроэлементов в фоновой пробе (ФП) 20 /15 (левый берег р. Ардон на южной окраине пос. Бурон) приведено в таблице 1. В пробе 29/15, при ее сравнении с ФП, установлены повышенные (в разы) содержания: Al, V, Fe, Co, U в 1.5; P, Ti, Mo, TI - в 1.4; Cr, Ni, Cu - в 1.6; Mn, Be, $\mathrm{Zr}$, Cs, La, Ce, Th - в 1.3; Zn - в 4.5; As - в 10.2; Pb - в 3.8; $\mathrm{Ag}$ - в 2.2; Cd - в 4.4; $\mathrm{Sn}$ - в 2.5; Sb - в 2.3; $\mathrm{Bi}$ - в 1.9 раза. Эти данные показали, что в р. Ардон перед Унальским хвостохранилищем произошло загрязнение ее вод вышеуказанными элементами за счет техногенных источников - шахтных вод, стекающих в боковые притоки, но ПДК (для питьевой воды) превышены (в разы) только для $\mathrm{Al}$ - в 9.9, Fe - в 11, As - в 1.3. Степень загрязнения оценивается как низкая, а масштабы - в 10 км.

Для оценки степени и масштабов загрязнения воды р. Ардон природными и техногенными постоянными источниками проведен сравнительный анализ проб воды, отобранных в пос. Бурон (ФП 20/15) и в г. Алагир (проба 36/15) на предгорной равнине, а также от Унальского хвостохранилища (проба 35/15) до г. Алагир (проба 36/15).

От пос. Бурон до г. Алагир. Сравнительный анализ проб 36/15 и ФП 20/15 показал, что в р. Ардон на протяжении 48 км от пос. Бурон и до г. Алагир произошло загрязнение вод за счет воздействия хвостохранилища с «защитным» озером и боковых притоков р. Ардон, выразившееся в увеличении (в разы) концентраций: В - в 5.1; $\mathrm{Na}$ - в 271; Mg, V и $\mathrm{Fe}$ - в 1.5; $\mathrm{Al}$ - в 1.8; $\mathrm{Si}$ - в 4.7; P - в 15; S - в 32.4; $\mathrm{K}$ - в 15.9; Сa - в 2.2; Тi - в 1.3; Mn и Y - в 1.4; Со и $\mathrm{Rb}$ - в 1.9; Ni - в 4.5; Cu - в 3.4; $\mathrm{Zn}$ - в 19.6; As - в 549; $\mathrm{Ba}$ - в 1.7; $\mathrm{Pb}$ - в 7.6; $\mathrm{Zr}$ - в 12.7; Mo - в 22; Sn - в 156; Sb - в 358; Cs - в 1.6; La и Ce - в 1.7; W - в 27.8; TI - в 1.8; Bi - в 45.4; U - в 1.8, но превышение (в разы) ПДК установлено для: Al - в 12.9; $\mathrm{Fe}$ - в 10.7; As - в 71; Sb - в 11.9. Приведенные данные показали среднюю степень загрязнения техногенными (хвостохранилище и шахтные воды) 


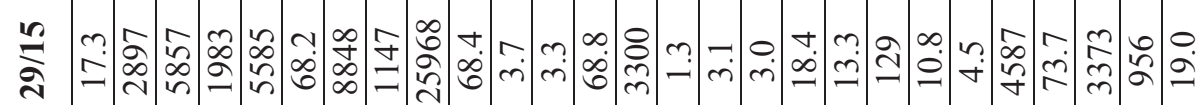

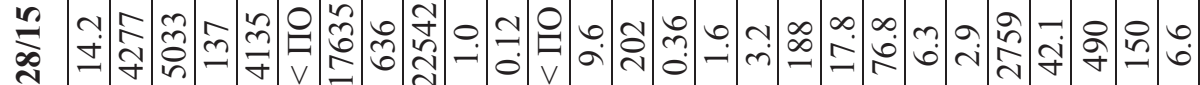

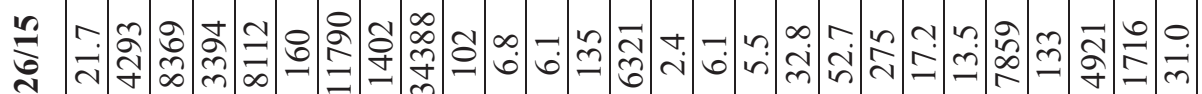

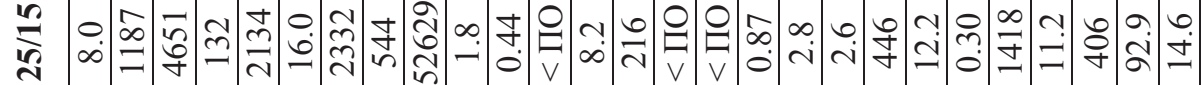

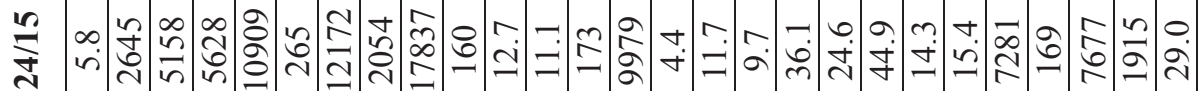

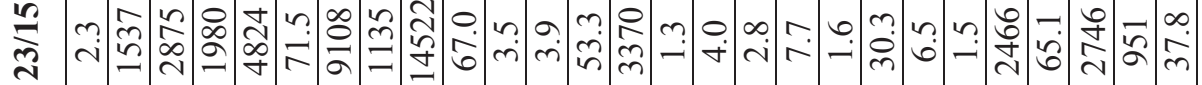

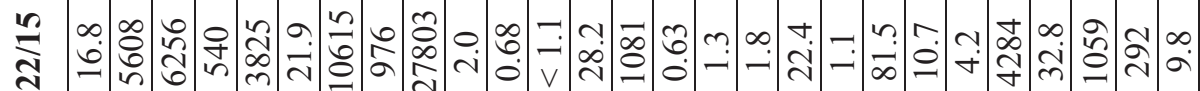

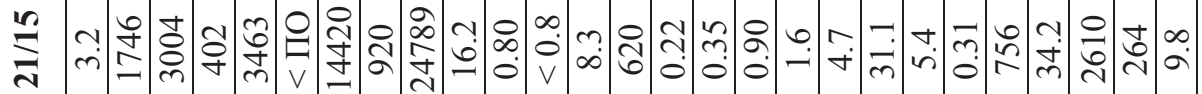

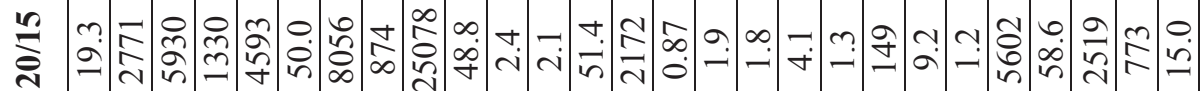

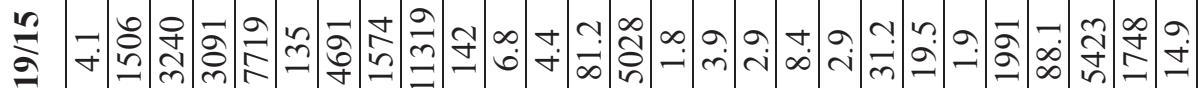

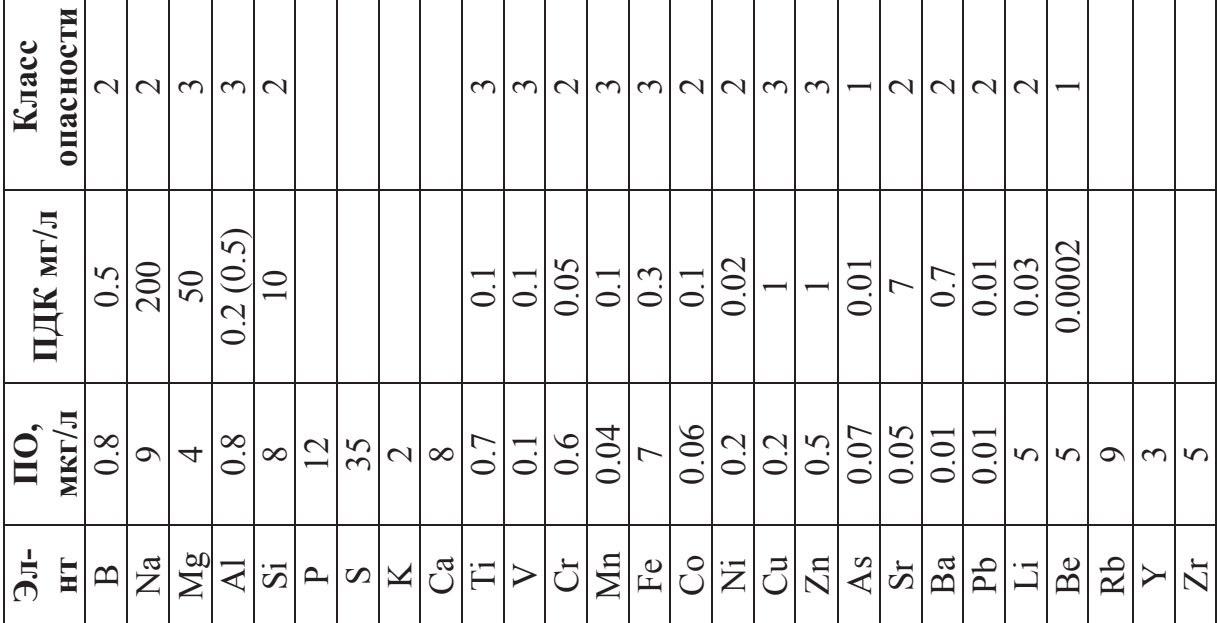




\section{УСТОЙЧИВОЕ РАЗВИТИЕ}

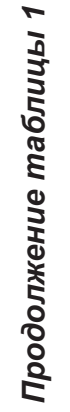

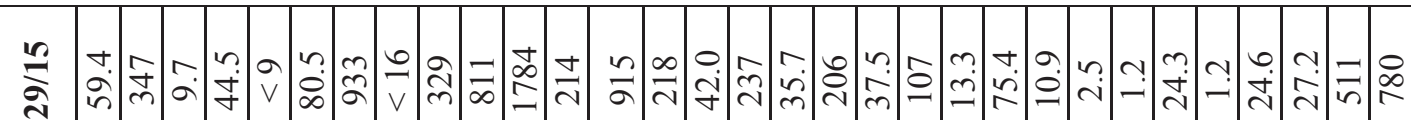

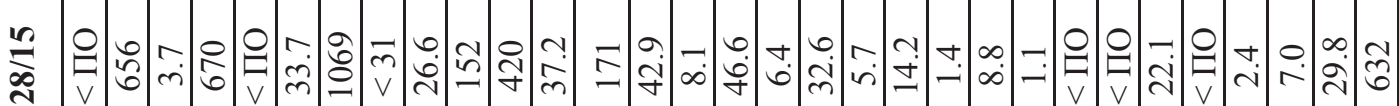

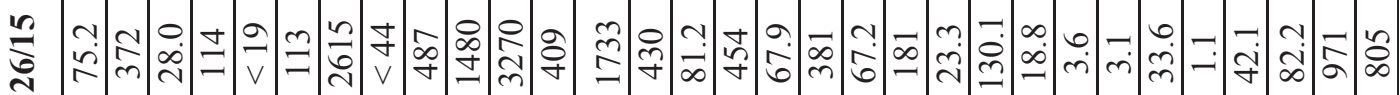

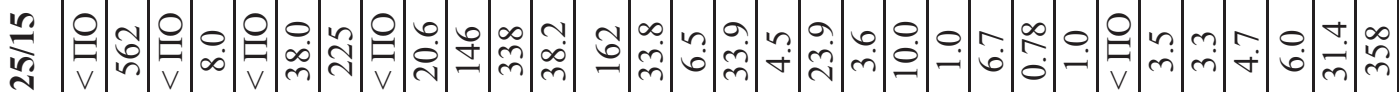

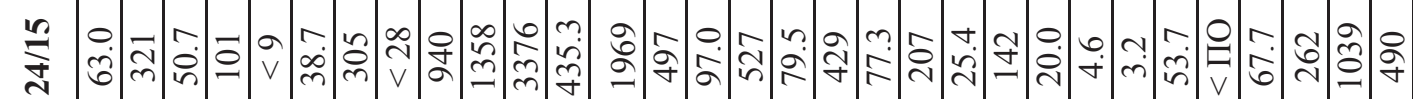

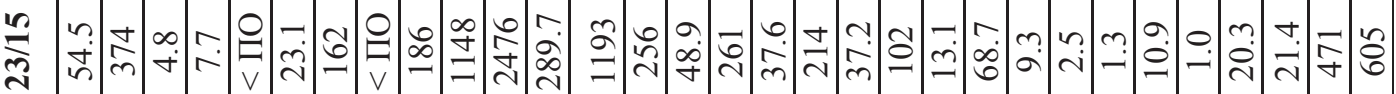

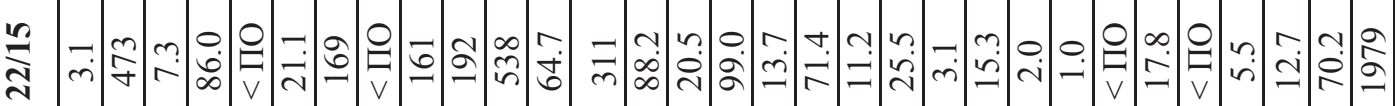

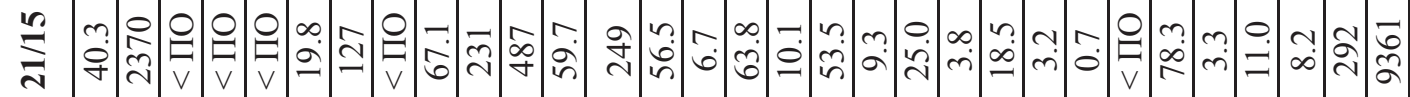

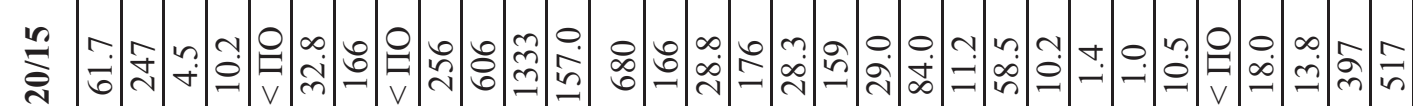

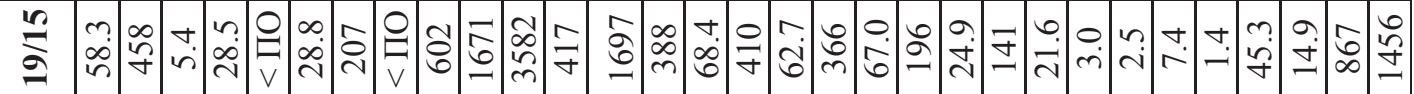

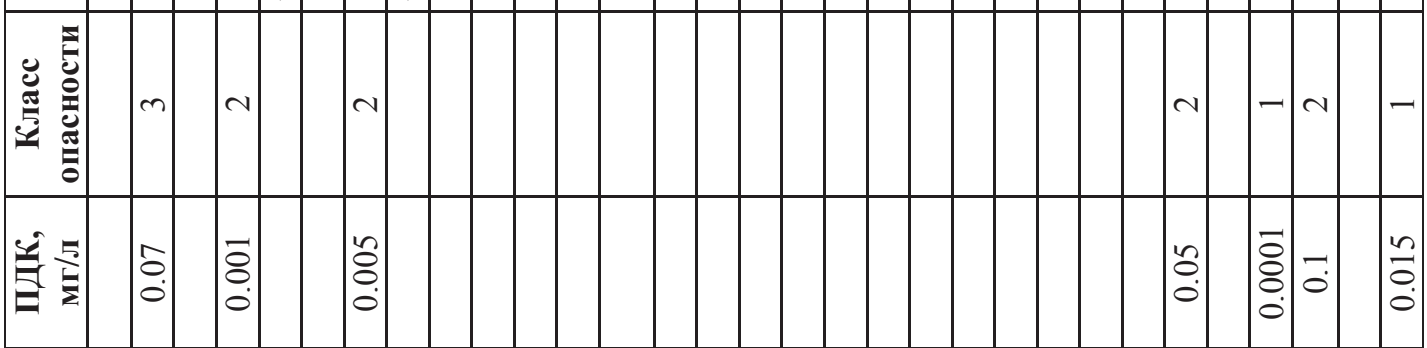

呈

กั่ 


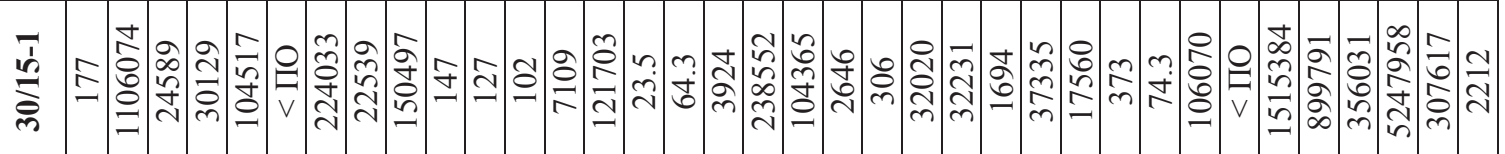

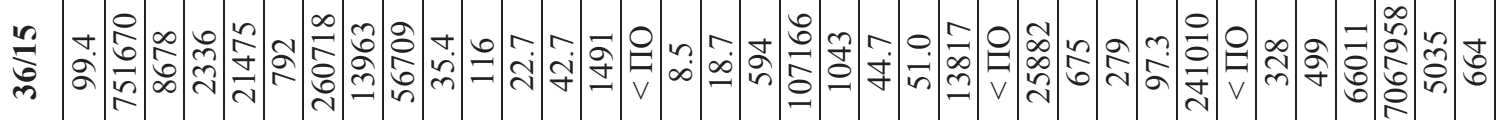

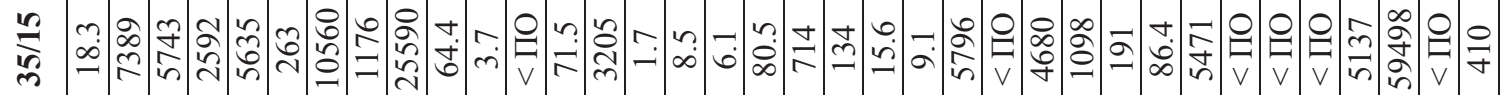

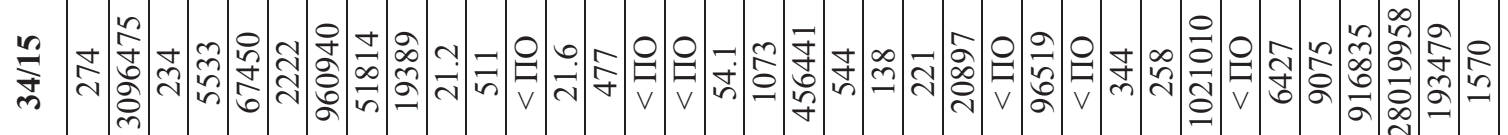

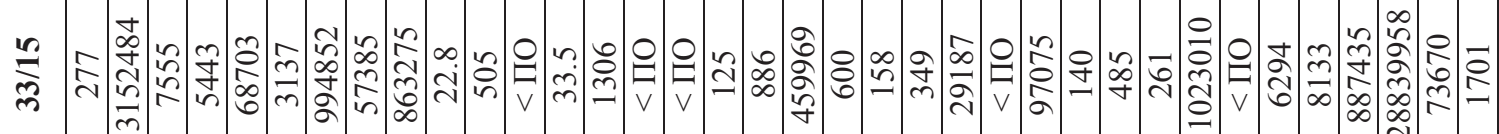

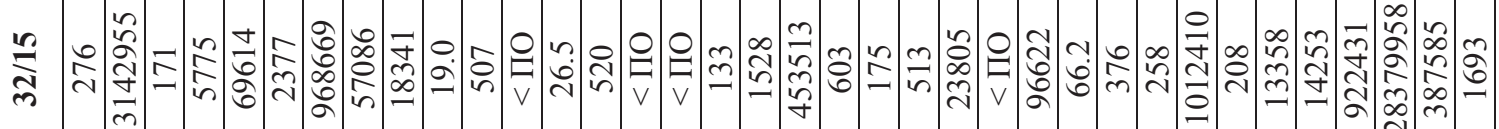

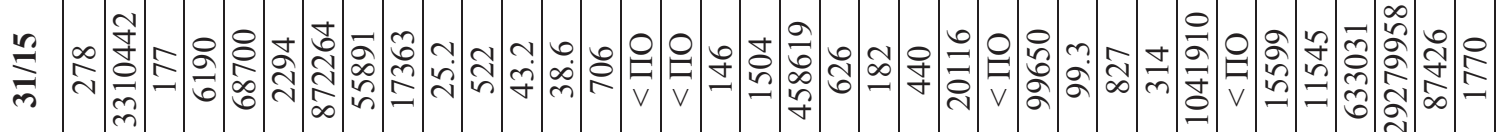

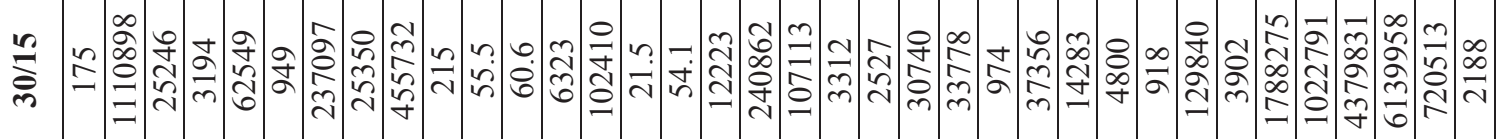

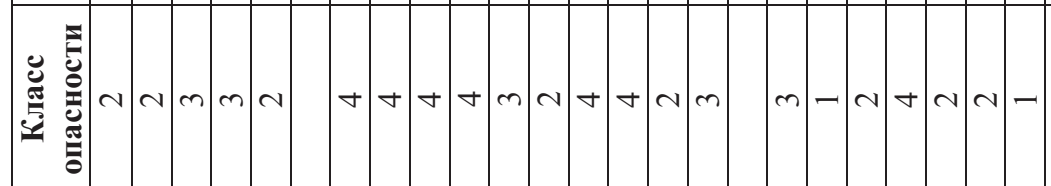

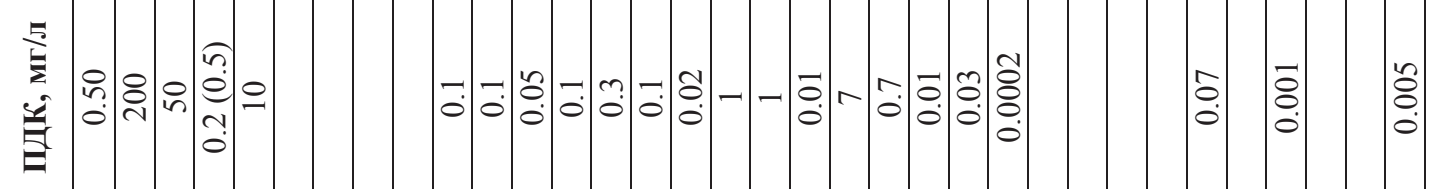

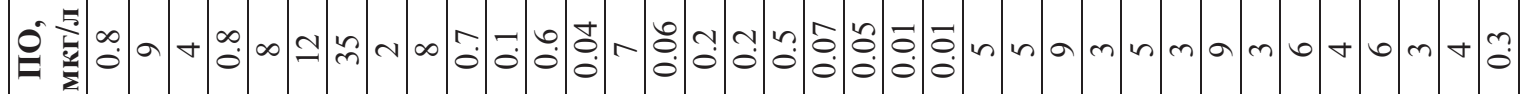

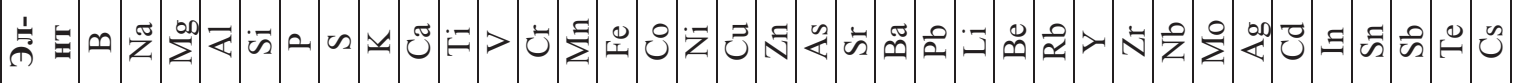




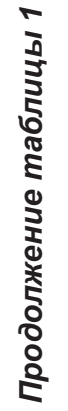

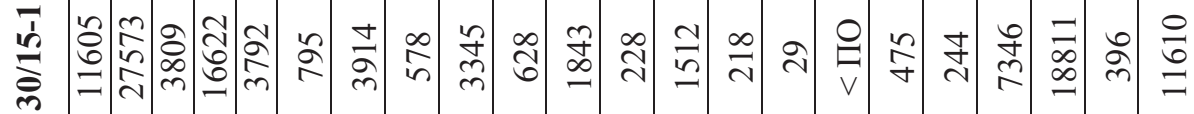

息

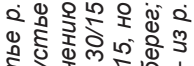

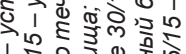

-

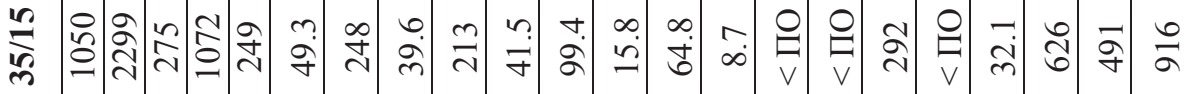

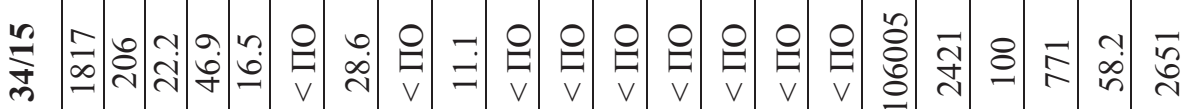

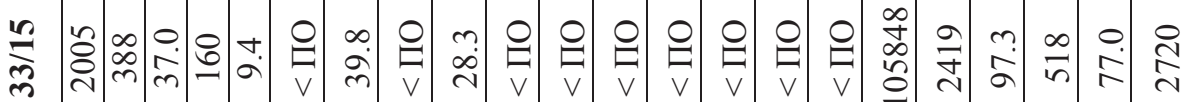

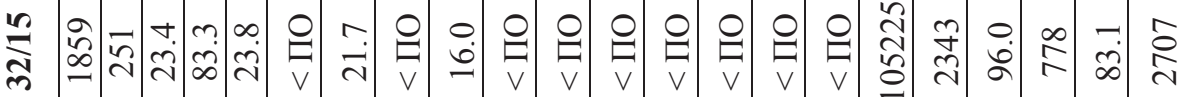

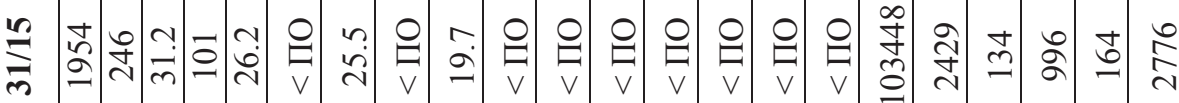

号

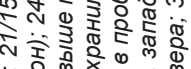

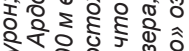

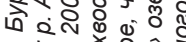

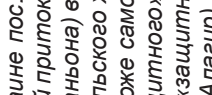

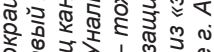

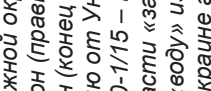

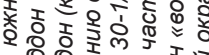

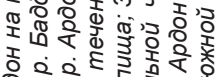

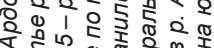

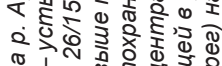

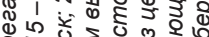

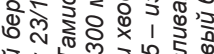

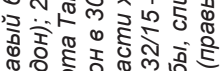

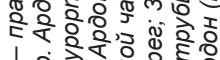

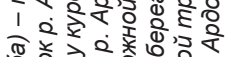

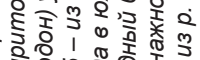

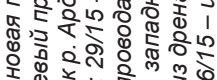

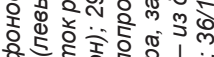

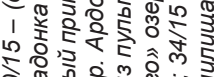

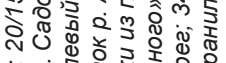

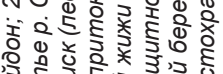

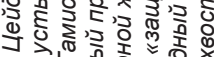

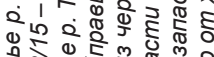

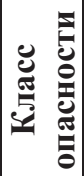

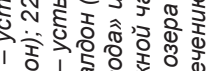

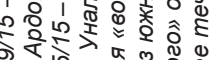

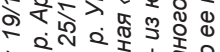

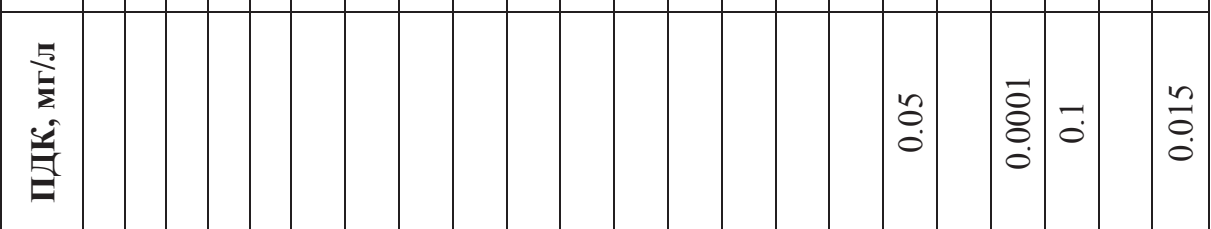

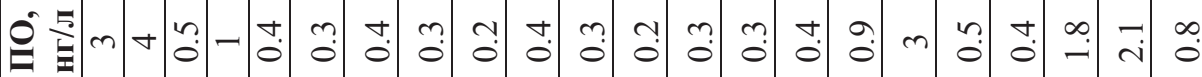

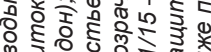

잉

옹ำ

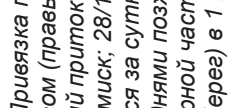

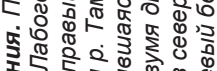

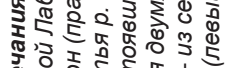

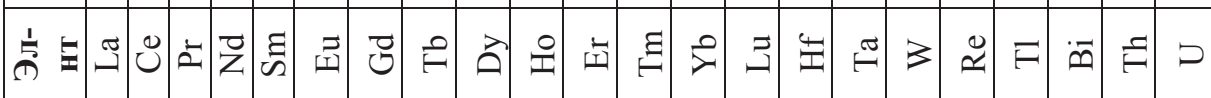


и природными (U и Au-W рудопроявления в верховьях р. Архон-дон) источниками вод р. Ардон на предгорной равнине перед г. Алагир, а его масштаб оценивается в 48 км.

От Унальского хвостохранилища до г. Алагир. Сравнительный анализ проб 36/15 и 35/15 показал, что в воде р. Ардон на южной окраине г. Алагир, по сравнению с водой в 1 км ниже хвостохранилища, произошло снижение (в разы) концентраций: Р - в 7.5; S - в 21; Fe - в 2.2; TI - в 1.5; и увеличение (в разы) концентраций: В - в 5.4; $\mathrm{Na}$ - в $3.7 ; \mathrm{Si}-$ в 2,1; $\mathrm{Cu}$ - в 3.2; Zn - в 7.4; As - в 150; Pb - в 5.6; Li - в 2.4; Rb - в 5.5; Mo - в 44; Cd - в 328; $\mathrm{Sb}$ - в 118.8; Te - в 503; W - в 87.2; U - в 1.4. Степень загрязнения оценивается как средняя, а ее масштаб - до 20 км.

\section{ВЫЯВЛЕНИЕ ОСНОВНЫХ ИСТОЧНИКОВ ЗАГРЯЗНЕНИЯ ВОД Р. АРДОН, ОЦЕНКА ИХ СТЕПЕНИ И МАСШТАБОВ СРЕДИ БОКОВЫХ ПРИТОКОВ И ВОДЫ «ЗАЩИТНОГО» ОЗЕРА}

Проба 19/15, вода из устья р. Цей-дон. Установлены превышения (в разы) ПДК для: $\mathrm{Al}$ - в 19.5; Fe - в 16.7. По сравнению с ФП 20/15 в ней установлены повышенные (в разы) содержания: Al и $\mathrm{Fe}-$ в 2.3; Si - в 1.7; P, La и Ce - в 2.7; Ti - в 2.9; V - в 2.8; $\mathrm{Cr}, \mathrm{Co}, \mathrm{Ni}, \mathrm{Zn}$ и Ba - в 2; Cu - в 1.5; As и Rb - в 2.2; Mo - в 1.9; Cd - в 2.8; Cs - в 2.4; TI, Th, Та и U - в 2.5. Следовательно, вода р. Цей-дон значительно (из-за большого дебита) загрязняла в 2015 г. воду в р. Ардон вышеуказанными элементами, а природными источниками загрязнения являются многочисленные рудопроявления в долине р. Цей-дон.

Проба 21/15, вода из устья р. Большой Лабогом (правый приток р. Ардон), характеризуется повышенными (в разы), по сравнению с ФП, концентрациями: As - в 3.6; Mo - в 9.6; W - в 7.5; Re - в 6.6; U - в 18.1. Превышения ПДК не установлены ни по одному элементу. Вода р. Большой Лабагом, из-за небольшого дебита, в малой степени загрязняет (природными источниками - из рудопроявлений) воду в р. Ардон этими элементами.

Проба 22/15, вода в устье р. Садонка, характеризуется повышенными (в разы), по сравнению с ФП, концентрациями: $\mathrm{S}$ - в $1.3 ; \mathrm{Zn}$ - в $5.5 ; \mathrm{Pb}-$ в 3.5; Be - в 1.8; Rb - в 2.4; Mo - в 1.9; Ag - в 1.6; $\mathrm{Cd}$ - в 8.4; W - в 1.7; U - в 3.8. Вода р. Садонки изза своего дебита слабо загрязняет воду в р. Ардон вышеуказанными элементами. Загрязнение вод $p$. Садонки $\mathrm{Pb}, \mathrm{Zn}, \mathrm{Cd}, \mathrm{Sb}, \mathrm{TI}, \mathrm{S}, \mathrm{U}$ обусловлено поступлением в них шахтных вод из штолен месторождений Верхний Згид и Садон, а U поступает из базальных конгломератов нижней юры.

Проба 23/15, вода в устье р. Бад-дон. Характерны повышенные (в разы), по сравнению с ФП, концентрации: Al, Co, V, Mo - в 1.5; Р и Ti - в 1.4; Cr, Zn, La и Ce - в 1.9; Fe, Cu и Bi - в 1.6; Pb - в 1.3; Li - в 2.3; $\mathrm{Zr}$ - в 2.5; $\mathrm{Ni}$ - в 2.2. Превышение ПДК (в разы) для питьевой воды установлено только для: Al - в 9.5; $\mathrm{Fe}$ - в 11. Вода р. Бад-дон в слабой степени загрязняет воду р. Ардон экологически опасными элементами из-за их низких концентраций

Проба 24/15, вода в устье р. Архон-дон. Ей присущи повышенные (в разы), по сравнению с ФП, концентрации: $\mathrm{Al}$ - в 4.2; $\mathrm{Si}$ - в 2.4; P - в 5.8; S - в 1.5; Ti - в 3.3; V и $\mathrm{Cr}$ - в 5.3; $\mathrm{Mn}$ - в 3.4; $\mathrm{Fe}$ - в 4.5; $\mathrm{Ni}$ - в 6.2; Cu - в 5.4; $\mathrm{Zn}$ - в 8.8; As - в 18.9; Ba - в 1.6; $\mathrm{Pb}$ - в 12.8; Li, Mo - в 1.3; $\mathrm{Be}$ - в 2.9; Rb - в 3; Y - в 2.5; Zr - в 1.9; Ag - в 11.3; Cd - в 9.9; Cs - в 3.7; W и Со - в 5.1; $\mathrm{Tl}$ - в 3.8; Bi - в 18.9; Th - в 2.6, а превышение (в разы) ПДК установлено для: $\mathrm{S}$ - в 1.2; Ti - в 1.6; Mn - в 1.7; Fe - в 33.3; As - в 2.5. Вода р. Архон-дон постоянно и в существенной степени загрязняет воду в р. Ардон вышеуказанными элементами. Повышенные содержания в воде ряда элементов обусловлены поступлением в нее шахтных вод с Архонского месторождения, a W наличием в истоках долины Au-W рудопроявлений, ассоциирующих с дайками лиственитизированных гипербазитов фриагдонского комплекса [3].

Проба 25/15, вода из устья р. Тамиск у курорта Тамиск. В ней не установлено превышение ПДК (для питьевой воды) ни для одного из элементов, и поэтому она практически не загрязняет воды р. Ардон.

Проба 28/15, вода из устья р. Унал-дон. Ей присущи повышенные (в разы), по сравнению с ФП, концентрации: S - в 2.2; Cu - в 1.8; Zn - в 45.8; As - в 13.7; $\mathrm{Sr}$ - в 1.9; $\mathrm{Ba}$ - в 1.5; $\mathrm{Pb}$ - в 2.4; Mo в 2.7; Cd - в 65.7; Sb - в 6.4; W - в 2.1; U - в 1.3 . Вода р. Унал-дон в слабой степени загрязняет воду в р. Ардон вышеуказанными элементами из-за их низких концентраций, несмотря на большой дебит реки. Загрязнение вод р. Унал-дон рядом тяжелых металлов обусловлено попаданием в них шахтных вод из месторождений Холст, Джимидон, Бозанг.

Пробы 30/15 и 30-1/15 (взяты с интервалом в двое суток) - отстоявшаяся через сутки прозрачная «вода» из черной жижи, сбрасываемой по пульпопроводу в южную часть хвостохранилища. В них установлено превышение (в разы) ПДК (для питьевой воды): $\mathrm{Na}$ - в 5.6 и 5.5 (соответственно в пробах 30/15 и 30-1/15 - здесь и далее); Al - в 16 и 150.5; $\mathrm{Si}$ - в 6.2 и 10.4; S - в 23.4 и 22.4; $\mathrm{Ti}$ - в 2. и 1.5; V - в 0.55 и 1.27; $\mathrm{Cr}$ - в 1.2 и 2; $\mathrm{Mn}$ - в 63 и 71; Fe - в 340 и 403; Ni - в 2.7 и 3.2; Zn - в 240.8 и 238.5; As - в 10711 и 10716; $\mathrm{Ba}$ - в 3.6 и 0.4; $\mathrm{Pb}-$ в 3074 и 3202; $\mathrm{Be}-$ в 4.9 и 8.5; Мо - в 1.8 и 1.5; Cd - в 1788 и 1515; Sn - в 39.8 и 33.2; Sb - в 12227.8 и 1049; TI - в 123.9 и 73.4. Следовательно, в хвостохранилище постоянно поступают хвосты обогащения, жидкая фраза которых (прозрачная «вода», появляющаяся после суток отстоя) содержит в виде коллоидной формы или истинных растворов элементы следующих классов опасности: 1-го - As, Be, Tl; 2-го - Si, Pb, $\mathrm{Cd}, \mathrm{Sb}$; 3-го - Al, Zn, Mn, Fe и 4-го - S. Такие высокие концентрации ряда элементов, не характерных для руд Садонского рудного поля, в отстоявшейся прозрачной «воде» из черной жижи, вытекающей из пульпопровода, свидетельствуют о том, что 1) на МГОФ перерабатываются привозные экологически опасные руды, или что 2) технологический процесс 
флотации на МГОФ необходимо совершенствовать для снижения негативной нагрузки на экологическую обстановку региона и его главную водную артерию - реку Ардон.

Сравнительный анализ геохимических особенностей проб воды из р. Ардон, взятых в 1.0 км ниже (проба 35/15) и в 0.3 км выше (проба 29/15) по течению реки от хвостохранилища, показал, что в пробе 35/15 появились повышенные (в разы), по сравнению с пробой 29/15, концентрации: $\mathrm{Na}$ - в 2.6; Al, Co, Li, La, Cе и TI - в 1.3; P - в 3.9; S - в 1.2; Ni - в 2.7; Cu и $\mathrm{Pb}$ - в 2; $\mathrm{Zn}$ - в 4.4; As - в 53.6; Ва и Rb - в 1.4; Sb - в 1001; Zr - в 10; Nb - в 1.5; Mo - в 15.8; Sn - в 63.8; W - в 12; Bi - в 23; U - в 1.2. Эти данные убедительно доказывают, что произошло значительное загрязнение вод р. Ардон водой, сливаемой из «защитного» озера и, за счет ветровой эрозии тонкодисперсного материала, обогащенного широким кругом элементов, с пляжной части хвостохранилища [4]. Превышение (в разы) ПДК (для питьевой воды) составило для: $\mathrm{Al}$ - 12.9; $\mathrm{Fe}$ - 10.6; As - 71.4; Sb - 11.9. Степень загрязнения оценивается как средняя, масштабы - в 1 км, а источник - техногенный.

Пробы «вод» 31/15 - из южной части, 32/15 из центральной части и 33/15 - из северной части «защитного» озера, вдоль его западного берега с глубины 20-25 см. В пробах установлено превышение (в разы) ПДК (для питьевой воды): $\mathrm{Na}$ - в 5.6-16.6-15.7 -здесь и далее в пробах 31/15, 32/15 и 33/15 соответственно); $\mathrm{Al}$ - в 31-29-27; Si - в 6.86.9-6.8; S - в 87.2-96.8-99.4; Са - в 0.1-0.1-4.8; V - в 5-5-5; Fe - в 2.3-1.7-4.3; $\mathrm{Zn}$ - в 1.5-1.5-0.88; As - в 45861-45351-45996; Pb - в 44-51.3-34.9; Мо - в 14.8-14.4-14.5; Cd - в 15.6-13.3-6; Sn - в 5.7-8.4-8; Sb - в 5840-5660-5760; W - в 2-2.1-2.1; TI - в 1.30.9-0.9. Следовательно, в хвостохранилище постоянно поступают хвосты обогащения, жидкая фраза которых содержит в коллоидной форме или в виде истинных растворов элементы следующих классов опасности:1-го - As; 2-го - Si, V, Pb, Cd, Sb; 3-го - Al, Мо и 4-го - S.

Проба 34/15 - «вода» из верхнего 3-6-сантиметрового слоя «защитного» озера, постоянно сливаемая по дренажной трубе в р. Ардон, характеризуется превышением (в разы) ПДК (для питьевой воды): $\mathrm{Na}$ - в 15.5; Al - в 27.5; Si - в 6.7; S - в 96; V - в $5 ; \mathrm{Fe}$ - в 1.6; Zn - в 1.07; As - в 45644; Pb - в 22 Mo - в 14.6; Cd - в 6.4; Sn - в 8.4; Sb - в 5638; W - в 2.1. Несмотря на малый объем «воды», сливаемой в р. Ардон, она из-за высоких концентраций широкого круга элементов довольно сильно загрязняет (смотри сравнительный анализ проб 29/15 и 35/15) воду реки: Al, Zn, As, Pb, Rb, Mo, Sb, W, TI, Y, Sn, La.

\section{ЗАКЛЮЧЕНИЕ}

Анализ полученных данных показал, что:

1. Основным источником техногенного загрязнения вод главной водной артерии района деятельности ССЦК - реки Ардон - является Унальское хвостохранилище. Загрязнение происходит двумя путями: за счет постоянного слива по дренажной системе осветленной воды из поверхностного слоя «защитного» озера и за счет ветровой эрозии тонкодисперсного материала (в нем установлены аномально высокие концентрации ряда экологически опасных элементов) [1]) с пляжной части хвостохранилища. Этот материал разносится постоянными ветрами, в виде пылевых облаков, вверх и вниз по долине на расстояние до 5-6 км, загрязняя воду р. Ардон и почвы природных пастбищ и сельхозугодий. Загрязнение достигает средней степени, а масштаб оценивается в 20 км.

2. Боковые притоки р. Ардон, имеющие техногенные (самоизливающиеся шахтные воды) и природные (уран из базальных конгломератов, а вольфрам из лиственитизированных гипербазитов фиагдонского комплекса нижнеюрского возраста) [3]) источники загрязнения, в слабой степени загрязняют воду р. Ардон и поэтому относятся к второстепенным, а масштаб их негативного воздействия оценивается в 30 км.

3. Суммарная средняя степень загрязнения вод р. Ардон на южной окраине г. Алагир (проба 36/15), по сравнению с фоновой пробой ФП 20/15, определена превышением (в разы) концентраций следующих элементов в пробе 36/15: В - в 5.1; $\mathrm{Na}$ - в 271; Mg, V, Fe - в 1.5; Al - в 1.8; Si - в 4.7; P - в 15; S - в 32.4; K - в 15.9; Ca - в 2.2; Ti - в 1.3; Mn, Y - в 1.4; Co, Rb - в 1.9; Ni - в 4.5; Cu - в 3.4; Zn - в 19.6; As - в 549; Ba - в 1.7; Pb - в 7.6; Zr - в 12.7; Mo - в 22; Sn - в 156; Sb - в 358; Cs - в 1.6; La, Ce - в 1.7; W в 27.8; TI - в 1.8; Bi - в 45.4; U - в 1.8, но превышение (в разы) ПДК (для питьевой воды) установлено для: $\mathbf{A l}$ - в 12.9; $\mathbf{F e ~ - ~ в ~ 1 0 . 7 ; ~ A s ~ - ~ в ~ 7 1 ; ~ S b ~ - ~ в ~ 1 1 . 9 . ~}$ Следовательно, фриксируется процесс интенсивного и постоянного загрязнения вод р. Ардон широким кругом элементов, среди которых имеются элементы: 1-го класса опасности - TI, As; 2-го класса - Co, $\mathrm{Ni}, \mathrm{B}, \mathrm{Si}, \mathrm{Pb}, \mathrm{W}, \mathrm{Bi}, \mathrm{Na}, \mathrm{Sb}$; 3-го класса - $\mathrm{Cu}, \mathrm{Zn}$, Мо. Масштаб загрязнения, по данным опробования 2015 г., оценивается в 48 км. Этими данными доказано, что в воде р. Ардон постоянно накапливаются элементы трех классов опасности, которые могут проникать, путем инфильтрации, в подземную гидросферу (водоносные горизонты) и накапливаться на природных геохимических барьерах, расположенных в низовьях долины р. Ардон или в долине р. Терек, после впадения в нее р. Ардон и далее до Каспийского моря.

4. Установлены в пробах воды (31/15 - «вода» из южной, 32/15 - «вода» из центральной и 33/15 - «вода» из северной частей «защитного» озера) превышения (в разы) ПДК (для питьевой воды) для: $\mathrm{Na}$ - в 5.6-16.6-15.7 (здесь и далее для проб 31/15, 32/15 и 33/15 соответственно); Al - в 31-29-27; Si в 6.8-6.9-6.8; S - в 87.2-96.8-99.4; Са - в 0.1-0.1-4.8; V - в 5-5-5; Fe - в 2.3-1.7-4.3; Zn - в 1.5-1.5-0.88; As - в 45861-45351-45996; Pb - в 44-51.3-34.9; Mo - в 14.8-14.4-14.5; Cd - в 15.6-13.3-6; Sn - в 5.78.4-8; Sb - в 5840-5660-5760; W - в 2-2.1-2.1; TI - в 
1.3-0.9-0.9. Это позволило предполагать, что такие высокие концентрации ряда элементов в воде «защитного» озера, не характерных для руд Садонского рудного поля, свидетельствуют о том, что: 1) на МГОФ перерабатываются привозные с других месторождений экологически опасные руды; 2) технологический процесс флотации на МГОФ необходимо совершенствовать для снижения негативной нагрузки на экологическую обстановку региона и его главную водную артерию - р. Ардон; 3) за длительное время хранения промышленных отходов в них, под влиянием внутренних (остатки химических реагентов фрлотации) и внешних (нагрев воды солнечной энергией) факторов, образовались в разной степени подвижные и растворимые минеральные формы или соединения ряда металлов; 4) за счет инфильтрации эти металлы могут проникать в подземную гидросферу и загрязнять водоносные горизонты, вода из которых на равнине (г. Алагир, пос. Ардон и др.) используется для полива сельхозугодий и питьевого водоснабжения населения.

5. На отрезке от хвостохранилища и до курорта Тамиск, расположенного при выходе реки на предгорную равнину, р. Ардон протекает в каньоне, где имеет большую скорость течения (2.3 м/сек), а далее на равнине и до впадения в р. Терек ее

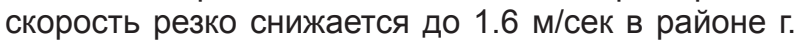
Алагир и до 1.5 м/сек ниже по течению реки. Это отразилось в разных мощностях и составах сформировавшихся донных осадков, что обусловлено тем, что на протяжении 55 лет (до 1 января 1984 г.) МГОФ (с производительностью до 20000 тонн руды/сутки) работала в режиме зимнего хранения хвостов и ежегодного их полного сбрасывания в р. Ардон в весенний паводковый период. В результате произошло их диффреренцированное отложение в аллювиальных донных речных отложениях. В каньоне, где скорость течения высокая, отложение тонкодисперсного материала хвостов в донных осадках было минимальным, а при выходе реки на предгорную равнину, где скорость ее течения резко снижалась, оно было максимальным. Донные осадки в равнинной части реки, обогащенные рудными минералами, могут постоянно поставлять (в виде взвесей, коллоидов или истинных растворов) в воду новообразованные подвижные минеральные формы или элементы и загрязнять ее. Это подтверждено результатами сравнительного геохимического анализа проб воды на равнине и в каньоне (в районе курорта Тамиск). Так, в воде р. Ардон, в ее равнинной части (окраина г. Алагир) наблюдаются превышения (в разы), по сравнению с водой на выходе из каньона, концентрации более широкого круга элементов: В - в 4.6; Na - в 175; $\mathbf{S i}-$ в 2.6; P - в 4.9; S - в 22; Ca - в 1.6; Ni - в 1.4; Cu - в 3.4; Zn - в 18; As - в 20.3; $\mathrm{Sr}$ - в 3.8; $\mathrm{Ba}$ - в 2.6; Pb - в 3.8; Li - в 1.8; Mo - в 648; Cd - в 2.9; Sn - в 5 842; Sb в 2 703; Cs - в 1.4; W - в 16.6; Bi - в 8.7; U - в 1.4 .

Работа выполнена по плану НИОКТР КНИО ВНЦ РАН: AАAA-A17-117060910043-8 на 2018 г. при финансовой поддержке Проекта 1.39 «Проблемно-ориентированные исследования техногенных отходов горнорудных предприятий Северного Кавказа и Забайкалья: размещение, вещественно-минеральный состав, оценка воздействия на экосистемы» в рамках Программы фундаментальных исследований Президиума РАН № 39 «Фундаментальные основы и энергоэффрективные, ресурсосберегающие, инновационные технологии переработки минерального сырья, утилизации промышленных и бытовых отходов».

Авторы статьи выражают искреннюю благодарность главе Унальского сельского поселения Алагирского района РСО-А Т.Б. Маргиеву за постоянную и бескорыстную помощь в проведении экспедиционных работ и опробовании хвостохранилища Мизурской обогатительной фабрики и сельхозугодий в населенных пунктах района.

\section{ЛИТЕРАТУРА}

1. Гурбанов А.Г., Шаззо Ю.К., Лексин А.Б. и др. Промышленные отходы Мизурской горно-обогатительной фабрики Садонского свинцово-цинкового комбината: геохимические особенности, оценка их воздействия на экологическую обстановку прилегающих территорий (почвы и воду р. Ардон), Республика Северная Осетия -Алания // Вестник ВНЦ PAH. 2012. T.12. №4 . C. 27-40.

2. Гурбанов А.Г., Винокуров С.Ф, Газеев В.М. и др. Содержание макро- и микроэлементов в поверхностных водотоках в районе деятельности Садонского свинцово-цинкового комбината (ССЦК) и на прилегающих территориях (Республика Северная Осетия-Алания, РФ) для выявления основных источников загрязнения гидросферы и меры по восстановлению экосистемы// Вестник ВНЦ РАН. 2016. Т. 16. № 2. C. $42-54$.

3. Гурбанов А.Г., Газеев В.М., Лексин А.Б., Докучаев А.Я. u др. Палеогеодинамические реконструкции и минерагения раннеюрского базальт-гипербазитового фиагдонского комплекса (Республика Северная Осетия-Алания, Кавказ, РФ) по петрохимическим, геохимическим и изотопным данным // Геология и геофизика Юга России. 2017. № 4. С. 22-38.

4. Гурбанов А.Г., Кусраев А.Г., Лолаев А.Б., Дзебоев С.О и др. Геохимические особенности промышленных отходов Мизурской горно-обогатительной фрабрики (Унальское хво- стохранилище, Республика Северная Осетия-Алания) как основа для оценки маситабов загрязнения ими почв прилегающих территорий // Геология и геофизика Юга России. 2018. № 1. C. ???

5. Матвеев А.А., Пряничникова Е.В., Шестакова Т.В. и др. Геохимическая оценка воздействия Унальского хвостохранилища Садонского свинцово-цинкового комбината (Северная Осетия-Алания) на окружающую среду // Изв. секции наук о Земле РАЕН. Вып. 12. М. 2004. С. 136-147.

6. Пряничникова Е.В. Оценка геолого-геохимического состояния природных сред в районе Унальского хвостохранилища ССЦК // 3-я экологическая конфреренция студентов и молодых ученых вузов г. Москвы «Охрана окружающей среды на пороге 3-го тысячелетия и в интересах устойчивого развития». М., 1999. С. 127-130.

7. Пряничникова Е.В. Оценка загрязнения поверхностных вод и донных отложений тяжелыми металлами в горнорудном районе // V Межвузовская молодежная научная конференция «Школа экологической геологии и рационального недропользования». СПб., 2004. С. 273-275.

8. Пряничникова Е.В. Эколого-геохимические исследования в горно-рудных районах (на примере Северной Осетии) // Вестник Московского университета. Серия 4. Геология. № 2. 2005. C. 48-54. 